\title{
PENGARUH MOTIVASI TERHADAP KEPUASAN KERJA KARYAWAN PERBANKAN DI JAKARTA
}

\author{
Anggaputra Perdana Halimun , Doniberatus Imantoro , F. Ken Wulandari, Herry Gunawan \\ Sibarani, Siti Agustina
}

\author{
anggaputra.ph@gmail.com, doniberatus.imantoro@gmail.com, \\ ken.wulandari.79@gmail.com, herry.sibarani1988@gmail.com,, \\ uthie.harahap92@gmail.com
}

\begin{abstract}
Banking is one of the most desirable destinations of job seekers in Jakarta, as well as being listed as the company with the highest employee turnover rate. This is interesting and become the main reason to do research in it. This study tries to explore how motivation can influence employee job satisfaction by determining motivation variables consisting of rewards, leadership style, work environment, and career development in banking industry in Jakarta, Indonesia. This study utilized quantitative survey method with total respondents of 188 people working at banks in Jakarta. The analysis technique used in this research is multiple linear regression using SPSS version 23.
\end{abstract}

Keywords: motivation, job satisfaction, employee, banking

\section{SARI PATI}

Industri perbankan merupakan salah satu bidang pekerjaan yang paling diminati oleh para pencari kerja di Jakarta, sekaligus tercatat sebagai perusahaan dengan tingkat perpindahan karyawan paling tinggi. Hal ini menarik dan menjadi alasan bagi kelompok kami untuk melakukan penelitian di dalamnya. Penelitian ini menelaah lebih dalam untuk mengetahui motivasi yang menentukan kepuasan kerja karyawan dengan menentukan variabel motivasi yang terdiri dari penghargaan, gaya kepemimpinan, lingkungan kerja, dan jenjang karir di sektor perbankan di Jakarta. Penelitian ini menggunakan metode survei kuantitatif dengan total responden 188 orang. Teknik analisis yang digunakan dalam penelitian adalah regresi linier berganda dengan menggunakan SPSS versi 23.

\section{PENDAHULUAN}

Industri perbankan merupakan salah satu penggerak pertumbuhan ekonomi di Jakarta, dimana saat ini Pemerintah Kota Jakarta tengah gencar melakukan pembangunan konstruksi dan infrastruktur. Sektor perbankan berperan sebagai penyalur dana dalam proyek-proyek pemerintah tersebut, dimana dibawah pengawasan Bank Indonesia yang telah menurunkan suku bunga nya selama 2 kali sepanjang tahun 2017 diharapkan dapat mendorong pertumbuhan ekonomi di Jakarta yang menjadi cerminan ekonomi secara nasional. Hal ini diharapkan dapat mendorong optimisme masyarakat sehingga perekonomian Jakarta dapat semakin menguat. Pertumbuhan ekonomi yang solid di triwulan I 2017 diiringi dengan terkendalinya inflasi di ibukota diharapkan dapat terus mendukung berlanjutnya perbaikan tingkat kesejahteraan masyarakat (Bank Indonesia 2017). Namun, dalam praktik operasional bank di Indonesia, terdapat data survei yang menyebutkan bahwa turnover rate karyawan bank termasuk tertinggi, yakni sekitar $16 \%$ di tahun 2015, sedangkan turnover rate rata-rata di industri lainnya sebesar $8 \%$ (Mercer Talent Consulting \& Information Solution 2015). 
Tingginya turnover karyawan bank tersebut merupakan permasalahan dalam pengelolaan sumber daya manusia. Dalam sebuah perusahaan, perilaku karyawan terbentuk oleh kebutuhan dalam diri karyawan dan motivasi yang mereka dapatkan untuk memuaskan kebutuhannya tersebut di tempat kerja. Motivasi ini dapat menentukan kepuasan kerja karyawan yang pada akhirnya dapat meningkatkan prestasi kerja, selain karena kemampuan karyawan sendiri. Menurut Frederick Herzberg (1964) dalam motivation hygiene theory, ada dua faktor ekstrinsik dan instrinsik yang mempengaruhi seseorang dalam bekerja. Faktor ekstrinsik merupakan faktor dari luar yang mempengaruhi seseorang dalam bekerja, contohnya adalah hubungan interpersonal antara atasan dengan bawahan, kebijakan administratif perusahaan, dan kondisi lingkungan kerja dan. Sedangkan faktor instrinsik merupakan faktor dari dalam diri yang meningkatkan prestasi individu, contohnya adalah pekerjaan yang menantang, kemampuan untuk berkembang, dan prestasi karyawan dalam perusahaan.

Berdasarkan pada latar belakang di atas, maka tujuan penelitian ini adalah untuk mengetahui seberapa besar motivasi kerja berpengaruh terhadap kepuasan kerja karyawan di industri perbankan di Jakarta. Variabel motivasi yang menjadi pertanyaan dalam penelitian adalah :

1. Seberapa besar penghargaan (rewards) baik secara financial maupun non financial berpengaruh terhadap kepuasan kerja karyawan di industri perbankan di Jakarta.

2. Seberapa besar gaya kepemimpinan (leadership style) berpengaruh terhadap kepuasan kerja karyawan di industri perbankan di Jakarta.

3. Seberapa besar lingkungan kerja (working environment) berpengaruh terhadap kepuasan kerja karyawan di industri perbankan di Jakarta.

4. Seberapa besar jenjang karir (career development) berpengaruh terhadap kepuasan kerja karyawan di industri perbankan di Jakarta.

Penelitian ini merupakan replikasi dari jurnal Influence of Motivation on Employee Job Satisfaction within the Telecommunication Industry in Kenya (A Case of Airtel Head Office in Nairobi County) (Kebaso \& Kanyua 2016).

\section{TINJAUAN PUSTAKA DAN PENGEMBANGAN HIPOTESIS}

Mempertahankan karyawan yang memiliki bakat adalah salah satu kunci kesuksesan sebuah organisasi. Menurut Buckingham dan Vosburgh (2001), dari semua faktor-faktor yang mempengaruhi efektivitas dari sebuah organisasi di masa depan adalah bakat. Berdasarkan, penelitian dari TalentKeepers pada tahun 2004, 78\% dari 240 organisasi yang diteliti, organisasi mengalami kehilangan pengetahuan organisasi ketika karyawan yang memiliki bakat mengundurkan diri dari perusahaan. Hal ini dapat memberikan dampak negatif terhadap produktifitas dan efektifitas sebuah organisasi.

Mayoritas penelitian mengenai kepuasaan kerja karyawan dan motivasi membicarakan twofactor theory dari Frederick Herzberg (1964), teori ini disebut juga motivation hygiene theory. Herzberg mengatakan bahwa ada dua tipe motivator, intrinsik dan ekstrinsik. Faktor intrinsik akan memotivasi seseorang ketika hal tersebut ada, sedangkan faktor ekstrinsik akan mengurangi motivasi ketika hal tersebut tidak ada. Hal ini disebabkan oleh ekspektasi seseorang. Faktor ekstrinsik meliputi gaji dan benefits, sedangkan faktor intrinsik meliputi hal-hal seperti pekerjaan yang menantang atau menarik dan pencapaian personal. Hal ini 
sesuai dengan teori hirarki kebutuhan oleh Maslow yang menyatakan bahwa seseorang harus memenuhi kebutuhan dasar seperti keamanan untuk mewujudkan perkembangan dan pertumbuhan pribadi mereka. Teori ini dapat digunakan oleh organisasi sebagai panduan bagaimana mereka dapat memperlakukan dan berhubungan dengan staf mereka. Organisasi perlu mengetahui bagaimana jenjang karir yang dijanjikan dapat memberikan dan mempengaruhi motivasi karyawan. Selain itu, organisasi juga perlu memperhatikan bagaimana gaya kepemimpinan atasan dapat menjadi salah satu variabel dalam memotivasi staf di dalam sebuah organisasi.

Membicarakan cara-cara mempertahankan karyawan, survei yang dilakukan oleh Collison dan Burke (2013) menemukan bahwa cara organisasi untuk mempertahankan karyawan yang paling umum adalah mengganti uang pendidikan, diikuti dengan manfaat liburan dan gaji yang kompetitif. Organisasi mulai menjadi lebih strategis dan inovatif dalam bagaimana mereka merancang program rewards organisasi untuk mempertahankan karyawan (Towers Perrin 2004).

Hal lain yang perlu dipertimbangkan adalah bagaimana lingkungan kerja mempengaruhi motivasi karyawan dan pada akhirnya kepuasaan kerja. Hubungan interpersonal antar karyawan menjadi salah satu hal penting dan patut dipertimbangkan selain adanya sumber daya dan kesehatan serta keamanan yang terjamin di dalam lingkungan kerja.

Dari teori-teori di atas, fokus penelitian adalah untuk mencari korelasi antara penghargaan, gaya kepemimpinan, lingkungan kerja, dan jenjang karir (variabel independen) dengan motivasi terhadap kepuasaan kerja karyawan (variabel dependen). Penghargaan meliputi penghargaan finansial (contohnya gaji dan tunjangan lembur) dan non-finansial (contohnya tunjangan pendidikan dan kesehatan). Gaya kepemimpinan meliputi otokratis (kekuasaan mutlak/terpusat pada pimpinan), partisipatif (mengikutsertakan karyawan pada pengambilan keputusan), dan laissez faire (tidak campur tangan). Lingkungan kerja yang diteliti meliputi kesehatan dan keamanan, sumber daya, dan hubungan interpersonal. Variabel jenjang karir yang akan diteliti adalah korelasi antara pelatihan untuk karyawan, sponsor, dan seminar/workshop terhadap motivasi karyawan. Adapun kerangka kerja konseptual dari penelitian ini dapat dilihat pada halaman berikutnya. Kerangka kerja berikut dimodifikasi dari Kebaso \& Kanyua (2016). 


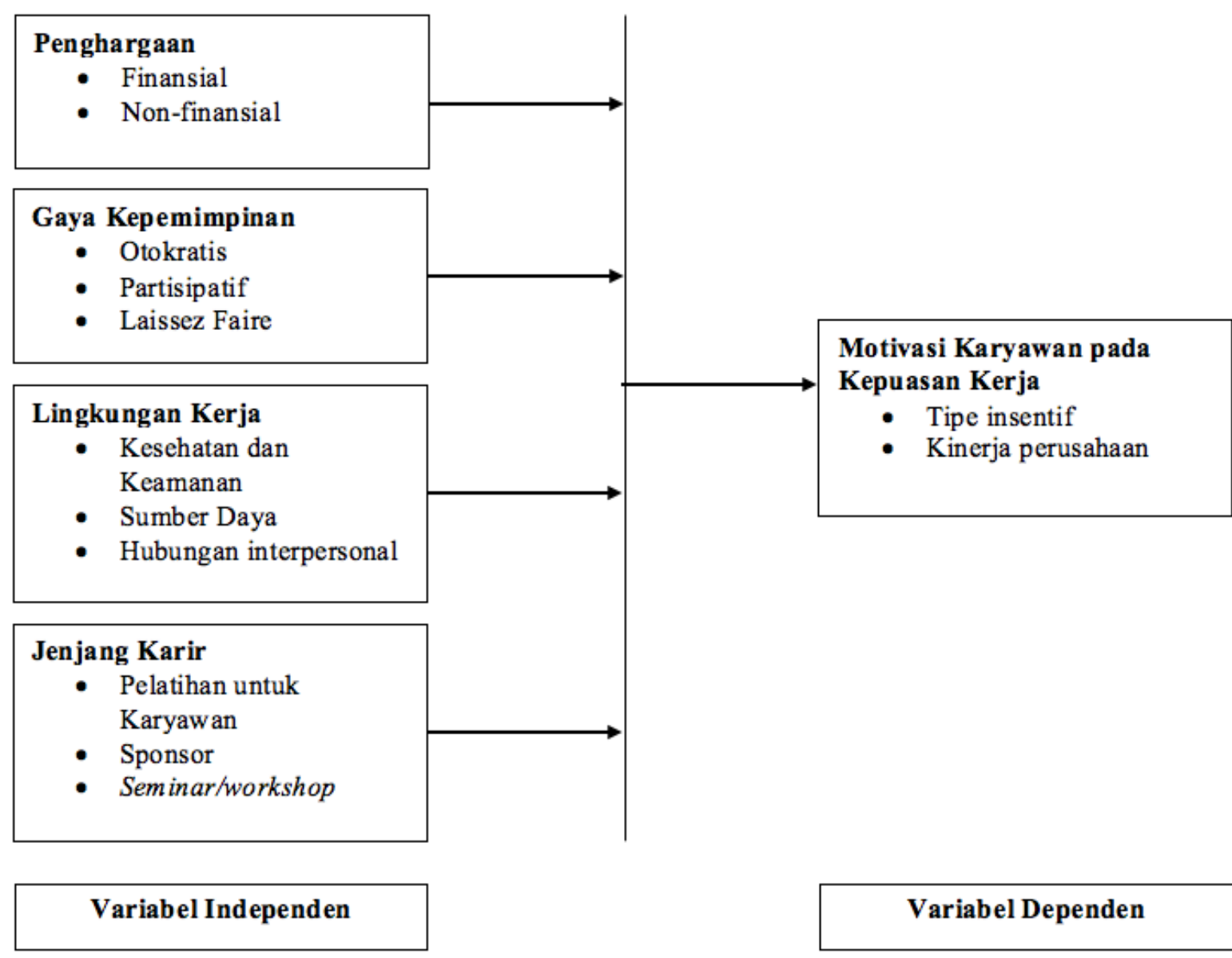

Gambar 1: Kerangka kerja konseptual penelitian (dimodifikasi dari Kebaso dan Kanyua, 2016)

\section{METODOLOGI PENELITIAN}

\section{Jenis dan Sumber Data}

Penelitian ini menggunakan data primer dan data sekunder. Data primer diperoleh dari sumber dengan menggunakan kuesioner, sedangkan data sekunder yaitu data yang diperoleh secara tidak langsung berupa penelitian terdahulu, studi pustaka dan jurnal-jurnal yang terkait dengan topik penelitian.

\section{Teknik Pengumpulan Data}

Teknik pengumpulan data yang digunakan dalam studi ini adalah dengan melakukan penyebaran kuesioner. Kuesioner yang disebar menggunakan model pertanyaan tertutup. Dalam pengukurannya, setiap responden diminta pendapatnya mengenai suatu pertanyaan dengan skala penilaian Likert dari nilai 1 (satu) sampai 7 (tujuh) dengan ketentuan nilai bobot 1 jika Sangat Tidak Setuju Sekali (STSS), nilai bobot 2 jika Sangat Tidak Setuju (STS), nilai bobot 3 jika Tidak Setuju (TS), nilai bobot 4 jika netral (N), nilai bobot 5 jika setuju (S), nilai bobot 6 jika Sangat Sangat Setuju (SS), dan nilai bobot 7 jika Sangat Setuju Sekali (SSS).

\section{Target Populasi}

Target populasi dari penelitian ini adalah karyawan bank di Jakarta. Rentang usia karyawan yang diamati adalah 21 tahun sampai dengan diatas 51 tahun. Tingkat pendidikan karyawan yang diamati tersebar pada tingkatan diploma, sarjana (S1), magister (S2), dan doktor (S3). 
Posisi karyawan dalam organisasi tersebar pada posisi posisi staf, manajer, asisten manajer, asisten VP, senior VP, dan direktur.

\section{Sampel dan Teknik Sampel}

Jumlah sampel yang digunakan dalam penelitian ini adalah 188 responden. Penentuan jumlah responden disebabkan oleh keterbatasan waktu penelitian.

\section{ANALISIS DATA}

Software SPSS versi 23 digunakan untuk menganalisis data. Begitu data diperoleh, data tersebut akan dimasukkan ke dalam software dan beberapa pengujian seperti regresi, korelasi, dan koefisien variasi akan dilakukan. Hasil dari pengujian tersebut akan dianalisis, disimpulkan dan menghasilkan beberapa rekomendasi.

\section{Informasi Umum}

\section{Distribusi usia responden}

Distribusi usia responden pada penelitian ini tersebar pada rentang usia 31-40 (52\%), usia 21-30 (32\%), usia 41-50 (13\%), dan usia di atas 50 tahun (3\%). Dari hasil penyebaran data tersebut dapat diamati bahwa mayoritas responden adalah karyawan yang termasuk dalam kategori usia muda.

Tabel 1: Penggolongan usia responden

\begin{tabular}{|c|c|c|}
\hline Rentang Usia & Jumlah Responden & Persentase (\%) \\
\hline $21-30$ & 61 & $32 \%$ \\
\hline $31-40$ & 97 & $52 \%$ \\
\hline $41-50$ & 24 & $13 \%$ \\
\hline$>50$ & 6 & $3 \%$ \\
\hline Total & 188 & $100 \%$ \\
\hline
\end{tabular}

\section{Distribusi jenis kelamin responden}

Komposisi jenis kelamin responden cukup seimbang antara responden laki-laki (51\%) dan responden perempuan (49\%).

\section{Gender Response}

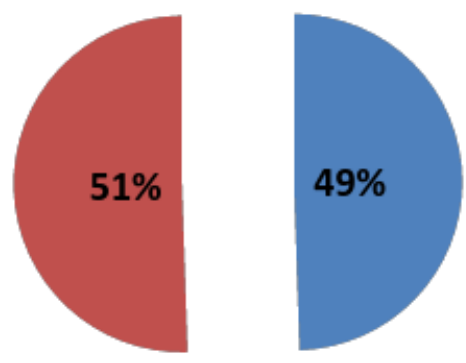

Laki-laki

Perempuan

Gambar 2: Distribusi jenis kelamin responden 


\section{Tingkat pendidikan responden}

Mayoritas responden bergelar Sarjana (79.8\%) disusul oleh responden dengan gelar Magister (18.6\%), Diploma (1.1\%) dan Doktor (0.5\%). Dari temuan tersebut dapat dikatakan bahwa mayoritas responden memiliki tingkat pendidikan yang tinggi. Dengan tingkat pendidikan yang tinggi tersebut dapat dikatakan pula bahwa tanggapan yang diberikan responden merupakan data terpercaya dan dapat digunakan untuk menganalisis pengaruh motivasi karyawan terhadap kepuasan kerja.

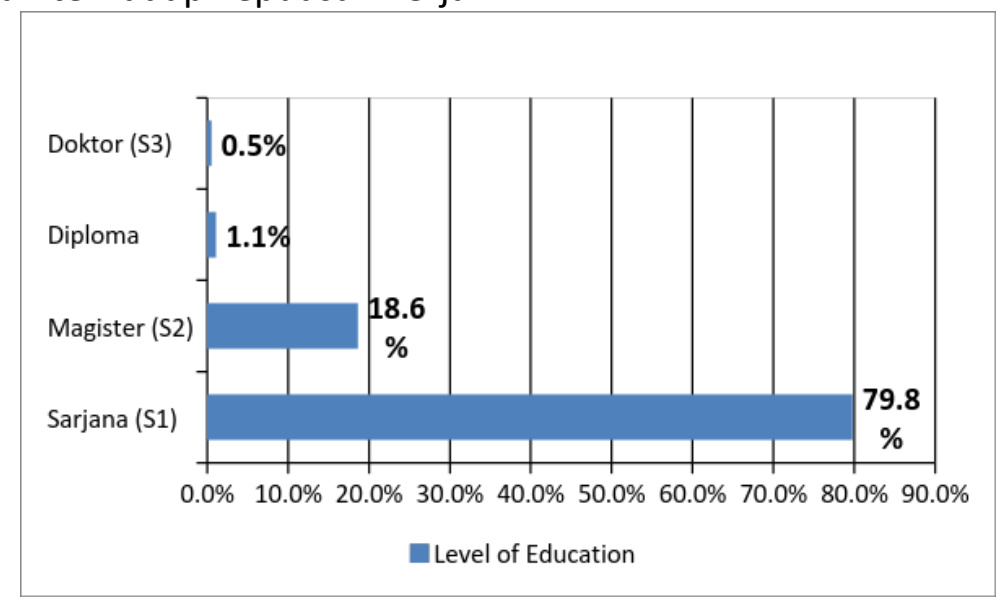

Gambar 3: Tingkat pendidikan responden

\section{Posisi di dalam organisasi}

Mayoritas responden berada di posisi manajer (27\%), disusul oleh posisi asisten manajer (26\%), staf (22\%), asisten VP (13\%), senior VP (3\%) dan direktur (1\%). Dapat disimpulkan bahwa mayoritas responden pada penelitian ini berada pada posisi middle management.

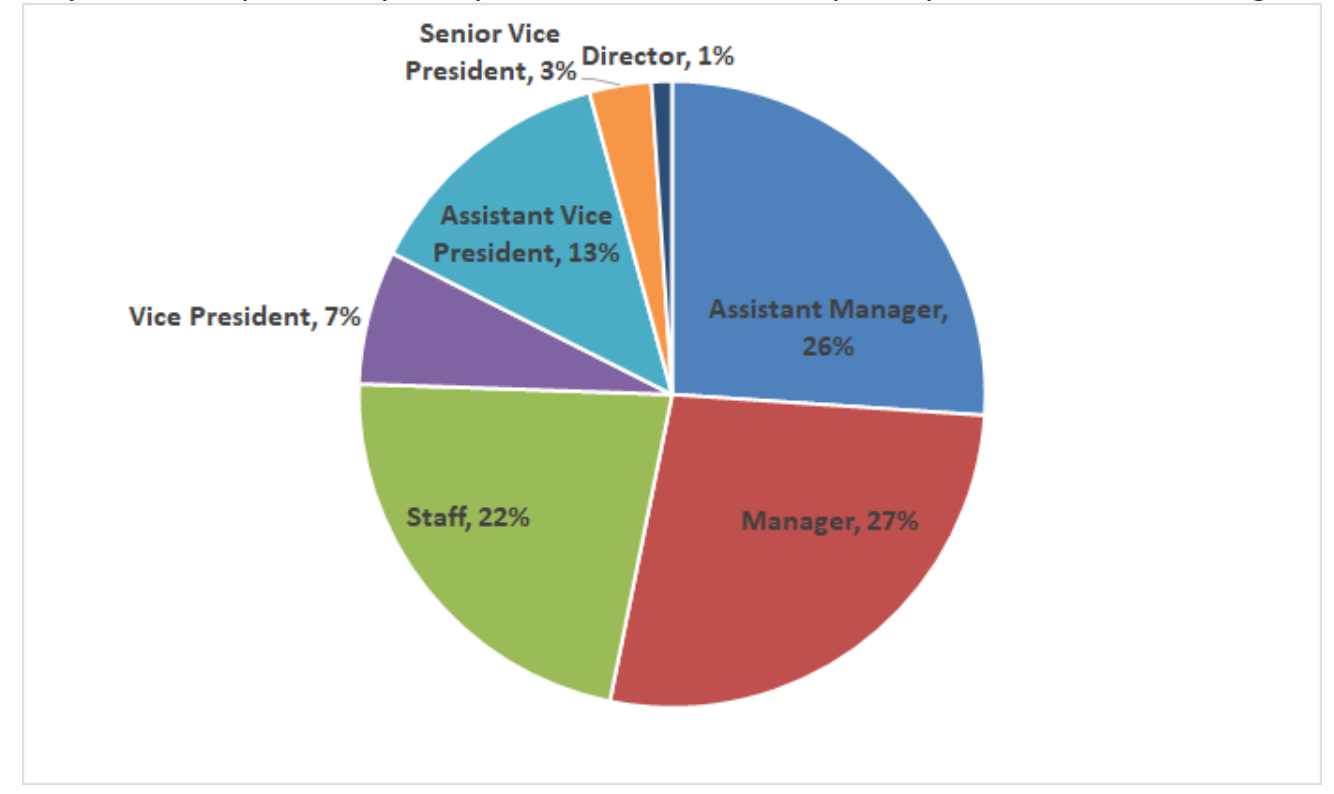

Gambar 4: Distribusi posisi responden di dalam organisasi

\section{Pengaruh Penghargaan terhadap Kepuasan Kerja Karyawan}

Diberikan 11 atribut penghargaan yang dicantumkan di dalam kuesioner dimana penghargaan tersebut mencakup penghargaan finansial dan non finansial. Penghargaan finansial diantaranya mencakup peningkatan gaji, tunjangan lembur, tunjangan pendidikan, tunjangan cuti, dan tunjangan kesehatan. Penghargaan non finansial diantaranya mencakup 
peningkatan tanggung jawab dalam bekerja, pengakuan terhadap hasil kerja dan pujian atas prestasi kerja. Dari sebaran data yang didapatkan dapat diamati bahwa mayoritas responden setuju untuk setiap atribut penghargaan yang didapatkan dengan akan memengaruhi kepuasan kerja, diantaranya $97.89 \%$ untuk peningkatan gaji, $86.56 \%$ untuk pemahaman atas penghargaan, 58.3\% untuk tunjangan lembur, $60.77 \%$ untuk tunjangan pendidikan atau beasiswa, $81.56 \%$ untuk tunjangan cuti, $87.61 \%$ untuk tunjangan kesehatan, 90.26\% untuk peningkatan tanggung jawab atas kreativitas bekerja, $96.89 \%$ untuk pengakuan terhadap hasil kerja, dan 93.3\% pujian atas prestasi kerja.

Dari beberapa atribut yang ditanyakan, peningkatan gaji menjadi atribut yang paling memengaruhi kepuasan kerja karyawan, disusul oleh pengakuan terhadap hasil kerja karyawan, pujian atas prestasi kerja karyawan, dan peningkatan tanggung jawab pekerjaan. 
Tabel 2: Pengaruh Penghargaan terhadap Kepuasan Kerja Karyawan

\begin{tabular}{|c|c|c|c|c|c|c|c|c|c|}
\hline & STSS & STS & TS & $\mathrm{N}$ & $\mathrm{S}$ & SS & SSS & Mean & Std Dev \\
\hline $\begin{array}{l}\text { Peningkatan gaji oleh manajemen memiliki pengaruh terhadap } \\
\text { motivasi dalam bekerja. }\end{array}$ & $0 \%$ & $0.17 \%$ & $0.25 \%$ & $1.69 \%$ & $8.85 \%$ & $32.38 \%$ & $56.66 \%$ & 6.31 & 0.88 \\
\hline $\begin{array}{l}\text { Saya memahami ruang lingkup (batasan) penghargaan yang } \\
\text { ditentukan oleh perusahaan. }\end{array}$ & $0 \%$ & $0.40 \%$ & $3.56 \%$ & $9.49 \%$ & $26.19 \%$ & $40.32 \%$ & $20.06 \%$ & 5.38 & 1.14 \\
\hline Penghargaan perusahaan terhadap kinerja saya sudah baik. & $0.67 \%$ & $2.24 \%$ & $7.05 \%$ & $12.98 \%$ & $31.32 \%$ & $35.57 \%$ & $10.18 \%$ & 4.76 & 1.45 \\
\hline Tunjangan lembur yang saya dapatkan sudah baik. & $4.32 \%$ & $6.69 \%$ & $8.37 \%$ & $22.32 \%$ & $23.01 \%$ & $22.59 \%$ & $12.69 \%$ & 3.81 & 1.85 \\
\hline $\begin{array}{l}\text { Tunjangan pendidikan (beasiswa) yang saya dapatkan sudah } \\
\text { baik. }\end{array}$ & $3.30 \%$ & $5.28 \%$ & $6.34 \%$ & $24.31 \%$ & $26.42 \%$ & $21.40 \%$ & $12.95 \%$ & 4.03 & 1.78 \\
\hline Gaji yang saya dapatkan sudah baik. & $0.91 \%$ & $1.60 \%$ & $6.86 \%$ & $16.46 \%$ & $38.29 \%$ & $24.69 \%$ & $11.20 \%$ & 4.65 & 1.42 \\
\hline Tunjangan cuti yang saya dapatkan sudah baik. & $0.73 \%$ & $1.25 \%$ & $3.13 \%$ & $13.33 \%$ & $25.52 \%$ & $31.25 \%$ & $24.79 \%$ & 5.11 & 1.50 \\
\hline Tunjangan kesehatan yang saya dapatkan sudah baik. & $0.29 \%$ & $1.17 \%$ & $2.34 \%$ & $8.59 \%$ & $19.51 \%$ & $38.05 \%$ & $30.05 \%$ & 5.45 & 1.38 \\
\hline $\begin{array}{l}\text { Peningkatan tanggung jawab karena kreativitas saya } \\
\text { meningkatkan kepuasan kerja. }\end{array}$ & $0.19 \%$ & $0.58 \%$ & $2.03 \%$ & $6.94 \%$ & $24.59 \%$ & $39.34 \%$ & $26.33 \%$ & 5.52 & 1.22 \\
\hline $\begin{array}{l}\text { Pengakuan terhadap hasil kerja yang baik dapat meningkatkan } \\
\text { kepuasan kerja saya. }\end{array}$ & $0 \%$ & $0.17 \%$ & $0.52 \%$ & $2.42 \%$ & $9.50 \%$ & $41.45 \%$ & $45.94 \%$ & 6.16 & 0.91 \\
\hline $\begin{array}{l}\text { Pujian yang saya dapatkan ketika saya berprestasi dapat } \\
\text { memberikan motivasi. }\end{array}$ & $0 \%$ & $0.18 \%$ & $0.80 \%$ & $5.71 \%$ & $13.39 \%$ & $38.04 \%$ & $41.88 \%$ & 5.96 & 1.04 \\
\hline
\end{tabular}

\section{Pengaruh Gaya Kepemimpinan terhadap Kepuasan Kerja Karyawan}

Diberikan 5 atribut gaya kepemimpinan yang dicantumkan di dalam kuesioner, diantaranya keterlibatan dalam pengambilan keputusan, pemberian kepercayaan untuk menyelesaikan masalah dalam pekerjaan, komunikasi yang baik dengan pimpinan, kerjasama tim, dan pemberian kesempatan untuk menetapkan target pribadi di perusahaan. Dari sebaran data yang didapatkan dapat diamati bahwa mayoritas responden setuju untuk setiap atribut gaya kepemimpinan akan mempengaruhi kepuasan kerja, diantaranya $87.83 \%$ untuk keterlibatan dalam pengambilan keputusan, $94.87 \%$ untuk pemberian kepercayaan untuk menyelesaikan masalah dalam pekerjaan, $90.51 \%$ untuk komunikasi yang baik dengan pimpinan, $88.58 \%$ untuk kerjasama tim, dan $80.11 \%$ untuk pemberian kesempatan untuk menetapkan target pribadi di perusahaan.

Dari beberapa atribut yang ditanyakan, atribut yang paling memengaruhi kepuasan kerja karyawan adalah komunikasi yang baik antara karyawan dan pimpinan sedangkan pemberian kesempatan bagi karyawan untuk menetapkan target masing-masing menempati posisi terendah.

\section{Tabel 3: Pengaruh Gaya Kepemimpinan terhadap Kepuasan Kerja Karyawan}

\begin{tabular}{lccccccccc}
\hline & STSS & STS & TS & N & S & SS & SSS & Mean & Std Dev \\
\hline Saya dilibatkan dalam pengambilan keputusan. & $0.20 \%$ & $0.59 \%$ & $2.67 \%$ & $8.70 \%$ & $26.71 \%$ & $40.36 \%$ & $20.77 \%$ & 5.38 & 1.22 \\
$\begin{array}{l}\text { Saya diberikan kepercayaan untuk menyelesaikan masalah } \\
\text { dalam pekerjaan. }\end{array}$ & $0 \%$ & $0.37 \%$ & $1.10 \%$ & $3.66 \%$ & $18.77 \%$ & $47.25 \%$ & $28.85 \%$ & 5.81 & 1.00 \\
Terdapat komunikasi yang baik antara saya dan pimpinan. & $0.58 \%$ & $0.97 \%$ & $1.74 \%$ & $6.20 \%$ & $18.39 \%$ & $42.98 \%$ & $29.14 \%$ & 5.49 & 1.42 \\
$\begin{array}{l}\text { Manajemen mendorong kerjasama tim yang dinamis untuk } \\
\text { membangun budaya kekompakan dalam lingkungan kerja. }\end{array}$ & $0.50 \%$ & $0.99 \%$ & $2.38 \%$ & $7.55 \%$ & $24.83 \%$ & $38.73 \%$ & $25.02 \%$ & 5.36 & 1.39 \\
$\begin{array}{l}\text { Saya diberikan kesempatan untuk menetapkan target saya } \\
\text { sendiri di perusahaan. }\end{array}$ & $0.64 \%$ & $1.93 \%$ & $4.49 \%$ & $12.83 \%$ & $26.74 \%$ & $34.65 \%$ & $18.72 \%$ & 4.97 & 1.49 \\
\hline
\end{tabular}




\section{Pengaruh Lingkungan Kerja terhadap Kepuasan Kerja Karyawan}

Diberikan 6 atribut lingkungan kerja yang dicantumkan di dalam kuesioner, diantaranya kejelasan dalam penyampaian metode kesehatan dan keselamatan kerja, ketersediaan sumber daya manusia yang cukup, hubungan interpersonal antar karyawan, lingkungan kerja yang kondusif, penyebaran informasi di dalam perusahaan, dan sarana dan prasarana yang tersedia. Dari sebaran data yang didapatkan dapat diamati bahwa mayoritas responden setuju untuk setiap atribut lingkungan kerja akan mempengaruhi kepuasan kerja, diantaranya $87.39 \%$ untuk kejelasan dalam penyampaian metode kesehatan dan keselamatan kerja, 76.67\% untuk ketersediaan sumber daya manusia yang cukup, $88.81 \%$ untuk hubungan interpesonal antar karyawan, $84.97 \%$ untuk lingkungan kerja yang kondusif, $84.76 \%$ untuk penyebaran informasi di dalam perusahaan, dan $90.11 \%$ untuk sarana dan prasarana yang tersedia.

Hubungan interpersonal yang baik antar karyawan dalam lingkungan kerja menjadi atribut yang paling memengaruhi kepuasan kerja karyawan, sedangkan ketersediaan sumber daya manusia yang cukup dalam perusahaan menjadi atribut yang paling rendah pengaruhnya. Namun dari data mean yang didapatkan para karyawan setuju atribut-atribut tersebut berperan dalam memengaruhi kepuasan kerja karyawan.

Tabel 4: Pengaruh Lingkungan Kerja terhadap Kepuasan Kerja Karyawan

\begin{tabular}{|c|c|c|c|c|c|c|c|c|c|}
\hline & STSS & STS & TS & $\mathrm{N}$ & $\mathrm{S}$ & SS & SSS & Mean & Std Dev \\
\hline $\begin{array}{l}\text { Terdapat kejelasan dalam penyampaian metode kesehatan dan } \\
\text { keselamatan kerja dalam lingkungan kerja. }\end{array}$ & $0.30 \%$ & $1.40 \%$ & $3.30 \%$ & $7.61 \%$ & $27.03 \%$ & $33.03 \%$ & $27.33 \%$ & 5.31 & 1.40 \\
\hline Terdapat sumber daya manusia yang cukup dalam perusahaan. & $0.11 \%$ & $3.01 \%$ & $5.16 \%$ & $15.05 \%$ & $24.73 \%$ & $31.61 \%$ & $20.32 \%$ & 4.95 & 1.45 \\
\hline $\begin{array}{l}\text { Terdapat hubungan interpersonal yang baik antar karyawan } \\
\text { dalam lingkungan kerja. }\end{array}$ & $0.29 \%$ & $0.20 \%$ & $2.06 \%$ & $8.64 \%$ & $27.48 \%$ & $40.04 \%$ & $21.30 \%$ & 5.42 & 1.19 \\
\hline Lingkungan tempat saya bekerja sudah kondusif. & $0.41 \%$ & $0.82 \%$ & $2.76 \%$ & $11.04 \%$ & $29.65 \%$ & $37.42 \%$ & $17.89 \%$ & 5.20 & 1.30 \\
\hline Penyebaran informasi di perusahaan berjalan secara efektif. & $0.51 \%$ & $1.24 \%$ & $1.54 \%$ & $11.95 \%$ & $28.32 \%$ & $42.02 \%$ & $14.42 \%$ & 5.16 & 1.32 \\
\hline $\begin{array}{l}\text { Fasilitas sarana dan prasarana (gedung, mobil, dll) terawat } \\
\text { dengan baik. }\end{array}$ & $0.50 \%$ & $0.80 \%$ & $3.00 \%$ & $5.59 \%$ & $29.47 \%$ & $38.96 \%$ & $21.68 \%$ & 5.32 & 1.34 \\
\hline
\end{tabular}

\section{Pengaruh Jenjang Karir terhadap Kepuasan Kerja Karyawan}

Diberikan 5 atribut lingkungan kerja yang dicantumkan di dalam kuesioner, diantaranya kebijakan yang jelas sebagai panduan dalam meniti jenjang karir, program pelatihan peningkatan karir dari perusahaan, dukungan manajemen dalam peningkatan karir, pemberian kesempatan atau sponsorship dari perusahaan dalam mengikuti pelatihan di luar perusahaan untuk peningkatan karir, dan diadakannya seminar atau workshop oleh perusahaan untuk pengembangan karir. Dari sebaran data yang didapatkan dapat diamati bahwa mayoritas responden setuju untuk setiap atribut jenjang karir akan mempengaruhi kepuasan kerja, diantaranya $80.44 \%$ untuk kebijakan yang jelas sebagai panduan dalam meniti jenjang karir, $80.73 \%$ program pelatihan peningkatan karir dari perusahaan, $79.56 \%$ untuk dukungan manajemen dalam peningkatan karir, $74.94 \%$ untuk pemberian kesempatan atau sponsorship dari perusahaan dalam mengikuti pelatihan di luar perusahaan untuk peningkatan karir, dan $75.64 \%$ untuk diadakannya seminar atau workshop oleh perusahaan untuk pengembangan karir.

Dukungan manajemen akan peningkatan karir karyawan menjadi atribut yang paling memengaruhi kepuasan kerja karyawan, sedangkan pemberian kesempatan (sponsorship) dari perusahaan untuk mengikuti program pelatihan peningkatan karir di luar perusahaan menjadi atribut terendah yang memengaruhi kepuasan kerja karyawan.

Tabel 5: Pengaruh Jenjang Karir terhadap Kepuasan Kerja Karyawan 


\begin{tabular}{|c|c|c|c|c|c|c|c|c|c|}
\hline & STSS & STS & TS & $\mathrm{N}$ & $\mathrm{S}$ & SS & SSS & Mean & Std Dev \\
\hline $\begin{array}{l}\text { Terdapat kebijakan yang memandu saya dalam meniti jenjang } \\
\text { karir yang jelas dalam perusahaan. }\end{array}$ & $0.98 \%$ & $1.97 \%$ & $6.56 \%$ & $10.05 \%$ & $27.87 \%$ & $33.44 \%$ & $19.13 \%$ & 4.87 & 1.59 \\
\hline Terdapat program pelatihan peningkatan karir dari perusahaan. & $0.75 \%$ & $2.15 \%$ & $5.17 \%$ & $11.19 \%$ & $29.60 \%$ & $27.77 \%$ & $23.36 \%$ & 4.94 & 1.56 \\
\hline Manajemen mendukung peningkatan karir saya. & $0.31 \%$ & $1.67 \%$ & $3.44 \%$ & $15.02 \%$ & $23.98 \%$ & $34.41 \%$ & $21.17 \%$ & 5.10 & 1.40 \\
\hline $\begin{array}{l}\text { Perusahaan memberikan kesempatan (sponsorship) untuk } \\
\text { mengikuti program pelatihan peningkatan karir di luar }\end{array}$ & $2.21 \%$ & $2.80 \%$ & $6.99 \%$ & $13.05 \%$ & $22.73 \%$ & $29.37 \%$ & $22.84 \%$ & 4.56 & 1.84 \\
\hline $\begin{array}{l}\text { Perusahaan sering mengadakan seminar dan workshop untuk } \\
\text { mengembangkan karir saya. }\end{array}$ & $1.01 \%$ & $2.46 \%$ & $7.04 \%$ & $13.85 \%$ & $24.58 \%$ & $31.51 \%$ & $19.55 \%$ & 4.76 & 1.62 \\
\hline
\end{tabular}

\section{Kepuasan Kerja Karyawan}

Dari sebaran data yang didapatkan dapat diamati bahwa $98.33 \%$ responden setuju bahwa peningkatan bonus dapat memotivasi karyawan untuk memperoleh kepuasan kerja, $96.55 \%$ responden setuju bahwa peningkatan kinerja perusahaan dapat memotivasi karyawan untuk memperoleh kepuasan kerja, dan $93.60 \%$ responden setuju bahwa komitmen direksi dapat memotivasi karyawan untuk memperoleh kepuasan kerja.

Dari sebaran kuesioner dapat dilihat bahwa atribut peningkatan bonus menjadi atribut yang paling memengaruhi motivasi karyawan untuk memperoleh kepuasan kerja, disusul oleh pengingkatan kinerja perusahaan dan komitmen dari direksi. Mayoritas karyawan setuju bahwa ketiga atribut yang diberikan akan memotivasi karyawan untuk memperoleh kepuasan kerja.

Tabel 6: Kepuasan Kerja Karyawan

\begin{tabular}{lcccccccccc}
\hline & STSS & STS & TS & N & S & SS & SSS & Mean & Std Dev \\
\hline $\begin{array}{l}\text { Peningkatan bonus dapat memotivasi saya untuk memperoleh } \\
\text { kepuasan kerja. }\end{array}$ & $0.00 \%$ & $0.17 \%$ & $0.50 \%$ & $1.00 \%$ & $9.17 \%$ & $25.52 \%$ & $63.64 \%$ & 6.38 & 0.89 \\
$\begin{array}{l}\text { Peningkatan kinerja perusahaan dapat memotivasi saya untuk } \\
\text { memperoleh kepuasan kerja. }\end{array}$ & $0.00 \%$ & $0.53 \%$ & $0.80 \%$ & $2.12 \%$ & $12.81 \%$ & $42.93 \%$ & $40.81 \%$ & 6.02 & 1.02 \\
$\begin{array}{l}\text { Komitmen direksi dapat memotivasi saya untuk memperoleh } \\
\text { kepuasan kerja. }\end{array}$ & $0.00 \%$ & $0.91 \%$ & $1.10 \%$ & $4.39 \%$ & $18.30 \%$ & $36.23 \%$ & $39.07 \%$ & 5.81 & 1.17 \\
\hline
\end{tabular}

\section{Analisis Regresi}

Analisis regresi adalah sebuah proses statistik yang lazim digunakan untuk mendapatkan estimasi hubungan antara variabel. Analisis ini termasuk dalam beberapa teknik untuk memodelkan dan menganalisis beberapa variabel yang lebih focus kepada hubungan antara satu variabel terikat dan satu atau lebih variabel bebas (Draper, 2012). Analisis regresi membantu untuk memahami perubahan yang akan terjadi kepada variabel terikat saat perubahan dilakukan pada sebuah variabel bebas, dan variabel bebas yang lain dipertahankan pada kondisi yang sama.

Tabel 7: Ringkasan Model Analisis Regresi

\begin{tabular}{|r|r|r|r|r|}
\hline \multicolumn{5}{|c|}{ Model Summary } \\
\hline 1 & $\mathrm{R}$ & $\mathrm{R}$ Square & $\begin{array}{c}\text { Adjusted } \\
\mathrm{R} \text { Square }\end{array}$ & $\begin{array}{c}\text { Std. Error } \\
\text { of the } \\
\text { Estimate }\end{array}$ \\
\hline
\end{tabular}

a. Predictors: (Constant), D, B, A, C

Dari hasil analisis diatas, nilai $\mathrm{R}$ Square yang didapatkan sebesar 0.207 yang berarti bahwa hanya ada $20.7 \%$ variasi pada kepuasan kerja yang disebabkan oleh perubahan dari penghargaan, gaya kepemimpinan, lingkungan kerja, dan jenjang karir pada nilai kepercayaan $95 \%$. Hal ini juga dapat berarti bahwa hanya $20.7 \%$ perubahan pada kepuasan kerja yang dapat diperhitungkan dari penghargaan, gaya kepemimpinan, lingkungan kerja, dan jenjang karir. $\mathrm{R}$ adalah koefisien korelasi yang menunjukkan hubungan antara variabel. 
Dapat juga disimpulkan bahwa 4 variabel yang ada memiliki hubungan yang tidak terlalu kuat yang ditunjukkan oleh angka 0.473 .

Tabel 8: Analysis of Variance ANOVA

\begin{tabular}{|c|c|c|c|c|c|c|}
\hline \multicolumn{7}{|c|}{ ANOVA $^{a}$} \\
\hline & & Sum of Squares & df & Mean Square & $\mathrm{F}$ & Sig. \\
\hline \multirow[t]{3}{*}{1} & Regression & 32.259 & 4 & 8.065 & 13.171 & $.000^{\circ}$ \\
\hline & Residual & 112.056 & 183 & .612 & & \\
\hline & Total & 144.315 & 187 & & & \\
\hline
\end{tabular}

a. Dependent Variable: $\mathrm{E}$

b. Predictors: (Constant), D, B, A, C

Dari statistic ANOVA pada tabel di atas, nilai significance level adalah 0.000 yang menunjukkan bahwa data ini ideal untuk dijadikan kesimpulan dari parameter populasi karena nilai significance ( $\mathrm{p}$-value) kurang dari $5 \%$. Kemudian menggunakan $\mathrm{F}$ table pada probabilitas $=0.05$ untuk data di atas, maka akan didapatkan nilai $F=2.42$. Karena nilai $F$ hitung (13.171) > F table (2.42) maka ada perbedaan yang signifikan di antara penghargaan, gaya kepemimpinan, lingkungan kerja, dan jenjang karir. Hal ini juga berarti bahwa penghargaan, gaya kepemimpinan, lingkungan kerja, dan jenjang karir berpengaruh secara signifikan terhadap kepuasan kerja.

Tabel 9: Hasil Koefisien Regresi

\begin{tabular}{|c|c|c|c|c|c|c|}
\hline \multicolumn{7}{|c|}{ Coefficients $^{3}$} \\
\hline \multirow{2}{*}{\multicolumn{2}{|c|}{ Model }} & \multicolumn{2}{|c|}{$\begin{array}{c}\text { Unstandardized } \\
\text { Coefficients }\end{array}$} & \multirow{2}{*}{$\begin{array}{c}\text { Standardized } \\
\text { Coefficients } \\
\text { Beta } \\
\end{array}$} & \multirow[b]{2}{*}{$\mathrm{t}$} & \multirow[b]{2}{*}{ Sig. } \\
\hline & & $\mathrm{B}$ & Std. Error & & & \\
\hline \multirow[t]{5}{*}{1} & (Constant) & 3.635 & .404 & & 9.003 & .000 \\
\hline & Penghargaan & .247 & .113 & .224 & 2.187 & .030 \\
\hline & Gaya Kepemimpinan & .166 & .087 & .198 & 1.910 & .058 \\
\hline & Lingkungan Kerja & -.030 & .093 & -.035 & -.321 & .748 \\
\hline & Jenjang Karir & .085 & .064 & 138 & 1.334 & .184 \\
\hline
\end{tabular}

a. Dependent Variable: E

Persamaan yang didapatkan adalah :

$$
Y=3.635+0.247 \times 10.166 \times 2-0.030 \times 3+0.085 \times 4
$$

Dari persamaan di atas, dapat disimpulkan bahwa dengan menjaga nilai penghargaan, gaya kepemimpinan, lingkungan kerja, dan jenjang karir pada nilai 0 secara konstan, maka kepuasan kerja akan berada pada nilai 3.635. Peningkatan 1 unit pada penghargaan akan meningkatkan kepuasan kerja pada faktor 0.247. Peningkatan 1 unit pada gaya kepemimpinan akan meningkatkan kepuasan kerja pada faktor 0.166. Peningkatan 1 unit pada lingkungan kerja akan menurunkan kepuasan kerja pada faktor 0.030. Peningkatan 1 unit pada jenjang karir akan meningkatkan kepuasan kerja pada faktor 0.085 . Nilai $p$ value lebih besar dari 0.05 mengindikasikan bahwa variabel tersebut tidak memiliki korelasi yang signifikan dengan variabel dependen. Hasil dari tabel di atas menunjukkan bahwa hanya 
variabel penghargaan yang secara statistik signifikan mempengaruhi kepuasan kerja, karena nilai $p$ value (sig) yang lebih kecil dari 0.05 .

\section{KESIMPULAN}

Informasi umum mengenai profil responden yang bekerja di industri perbankan yaitu secara umum responden tergolong dalam kategori usia muda dengan komposisi laki-laki dan perempuan yang cukup seimbang, mayoritas responden berpendidikan relatif tinggi, dan berada pada posisi middle management di perusahaan.

Hasil dari penelitian ini menyimpulkan bahwa keempat variabel bebas yang dipakai (penghargaan, gaya kepemimpinan, lingkungan kerja, dan jenjang karir) berkorelasi dengan kepuasan kerja.

Variabel penghargaan memiliki pengaruh yang paling signifikan terhadap kepuasan kerja pegawai perbankan di Jakarta, Indonesia. Penghargaan (khususnya penghargaan non finansial) memiliki peranan yang penting dalam membangun dan mempertahankan motivasi kerja sehingga meningkatkan kepuasaan kerja karyawan di industri perbankan di Jakarta.

Hasil lebih lanjut dari penelitian ini juga menyatakan bahwa pengaruh gaya kepemimpinan, lingkungan kerja, dan jenjang karir tidak memiliki hubungan yang signifikan terhadap kepuasan kerja.

\section{Rekomendasi}

Penelitian ini merekomendasikan perusahaan dalam industri perbankan untuk fokus pada variabel penghargaan. Perusahaan dapat membuat pedoman umum dalam pemberian penghargaan bagi pegawai yang dapat memotivasi pegawai yang akan berujung pada kepuasan kerja pegawai. Selain itu, perusahaan juga dapat membuat program dan pelatihan untuk tingkat manajemen perusahaan sehingga dapat membuat lingkungan kerja yang kondusif bagi seluruh pegawai.

Untuk peningkatan kualitas penelitian selanjutnya direkomendasikan untuk menambah jumlah sampel responden sehingga didapatkan hasil yang lebih akurat. Pilot study disarankan untuk dilakukan dalam penyusunan pertanyaan kuesioner untuk memverifikasi faktor-faktor yang berperan pada industri perbankan di lokasi penelitian. Selain itu, studi ini dapat diekspansi untuk mempelajari faktor yang paling signifikan di industri lain, misalnya di industri non servis. Eksplorasi juga dapat dilakukan terhadap temuan utama dari studi ini, yaitu apakah penghargaan yang menjadi faktor utama di industri perbankan juga menjadi faktor penentu pada industri lainnya. 


\section{DAFTAR PUSTAKA}

Bank Indonesia Website : Kajian Ekonomi dan Keuangan Regional Provinsi DKI Jakarta 2017, http://www.bi.go.id/id/publikasi/kajian-ekonomiregional/jakarta/Pages/Kajian-Ekonomi-dan-Keuangan-Regional-Provinsi-DKIJakarta-Mei-2017.aspx; (5 Agustus 2017)

Buckingham, M. \& Vosburgh, R. (2001). "The 21st Century Human Resources Function: It's the Talent, Stupid!" Human Resource Planning, 24(4): 17-23.

Collison, J. \& Burke, M (2003), "Job Recovery Survey," SHRM Research, September:7.

Draper, N. R. \& Smith, H. (2014). "Applied Regression Analysis, Third Edition”. John Wiley \& Sons, Inc.

Elkjaer, D. \& Filmer, S. (2015). "Trends and Drivers of Workforce Turnover: The Results from Mercer's 2014 Turnover Survey, and Dealing with Unwanted Attrition". Mercer Talent Consulting \& Information Solution.

Herzberg, F. (1964). "The Motivation-Hygiene Concept and Problems of Manpower". Personnel Administrator (27): 3-7.

Maslow, A. H. (1943). “A Theory of Human Motivation”. Psychological Review, 50: 370396.

Kebaso, Maureen K. \& Kanyua, Dr. Esther (2016), "Influence of Motivation on Employee Job Satisfaction within the Telecommunication Industry in Kenya (A Case of Airtel Head Office in Nairobi County)", International Journal of Innovative Development \& Policy Studies 4(3):33-52, July-Sept.,2016

TalentKeepers Research Report (2004). "Employee Retention Trends, Spring 2004." TalentKeepers.

The Bisnis Website, http://finansial.bisnis.com/read/; (2 Agustus 2017)

The Universum Global Website, http://universumglobal.com/ideal-employerrankings/student-surveys/; (2 Agustus 2017)

Towers Perrin. (2004). "Reward and Performance Management Challenges, Linking People and Results," April. 
LAMPIRAN 